\title{
Metal rich particulate matter impairs acetylcholine-mediated vasorelaxation of microvessels in mice
}

\author{
Azita K Cuevas', Jingping Niư ${ }^{2}$, Mianhua Zhong ${ }^{1}$, Eric N Liberda' ${ }^{1}$, Andrew Ghio ${ }^{3}$, Qingshan Qu ${ }^{1}$ \\ and Lung Chi Chen ${ }^{1 *}$
}

\begin{abstract}
Background: Exposure to $\mathrm{PM}_{2.5}$ (particulate matter $<2.5 \mu \mathrm{m}$ ) has been associated with changes in endothelial function. $\mathrm{PM}_{2.5}$ was collected from two Chinese cities, Jinchang (JC) and Zhangye (ZH), both with similar $\mathrm{PM}_{2.5}$ concentrations. However, JC had levels of nickel (Ni), selenium (Se), copper (Cu), and arsenic (As) that were 76, 25, 17, and 7 fold higher than that measured in $\mathrm{ZH}$, respectively. We used this unique PM sample to delineate the chemical components that drive pulmonary and systemic effects and explore the mechanism(s) by which vascular dysfunction is caused.
\end{abstract}

Methods: Male FVB/N mice received oropharyngeal aspiration of water or $\mathrm{PM}_{2.5}$ from JC, ZH or ZH spiked with one of the following elements at the same concentrations found in the JCPM ( Ni=4.76; As = 2.36; Se=0.24; Cu=2.43 $\mu \mathrm{g} / \mathrm{mg})$ followed by evaluation of markers of pulmonary and systemic inflammation. Mesenteric arteries were isolated for gene expression or functional response to various agonists (Phenylephrine, Acetylcholine, and Sodium Nitroprusside) and inhibitors (L-NAME, Apocynin, and VAS2870) ex vivo.

Results: Protein and total cell counts from lung lavage revealed significant pulmonary inflammation from ZH ( $p<0.01$ ) and $\mathrm{JC}$ and $\mathrm{ZH}+\mathrm{NiSO}_{4}(\mathrm{p}<0.001)$ as compared to control and a significant decrease in mesenteric artery relaxation $(p<0.001)$ and this decrease is blunted in the presence of NADPH oxidase inhibitors. Significant increases in gene expression (TNF-a, IL-6, Nos3; $\mathrm{p}<0.01$; NOX4; $\mathrm{p}<0.05$ ) were observed in $\mathrm{JC}$ and $\mathrm{ZH}+\mathrm{NiSO}$, as well as significantly higher concentrations of VEGF and IL-10 ( $p<0.01, p<0.001$; respectively).

Conclusions: Our results indicate that the specific toxicity observed in PM from JC is likely due to the nickel component in the PM. Further, since VAS2870 was the most successful inhibitor to return vessels to baseline relaxation values, NADPH Oxidase is implicated as the primary source of PM-induced $\mathrm{O}_{2}^{-2}$.

Keywords: Vascular function, Endothelial dysfunction, Nickel, Air pollution, Particulate matter, Endothelial nitric oxide uncoupling, Nicotinamide adenine dinucleotide phosphate (NADPH) oxidase

\section{Background}

Ambient air pollution continues to adversely affect millions of people globally. According to the World Health Organization [1], approximately 2.4 million people die prematurely each year from causes directly attributable to air pollution, and an even greater number of people bear the burden of health conditions exacerbated by air

\footnotetext{
* Correspondence: Lung-Chi.Chen@nyumc.org

'Department of Environmental Medicine, New York University School of Medicine, 57 Old Forge Road, Tuxedo 10987, NY, USA

Full list of author information is available at the end of the article
}

pollution. These findings are supported by epidemiological studies showing that both short and long term exposures to high levels of ambient particulate matter (PM) lead to increased risk of diabetes, hypertension, and other cardiovascular-related diseases and death [2-6]. However, the precise mechanism(s) by which the PM-induced damage occurs and the PM component(s) responsible for the induced effects remain unknown.

Human and animal experiments using PM samples rich in transition metals have reported a myriad of pathologies. Several groups of investigators have reported 
increased thrombosis and impaired fibrinolysis within 24 hours of PM exposure [7-9]. A human study by Sangani et al. [10] found water-soluble metal components (e.g. $\mathrm{Al}, \mathrm{Fe}, \mathrm{Ca}, \mathrm{Ni}, \mathrm{Cu}, \mathrm{Pb}, \mathrm{V}$ and $\mathrm{Zn}$ ) of PM significantly decreased whole blood coagulation time in healthy subjects. It is also believed that increases in oxidative stress play a major role in increasing blood pressure and driving procoagulative events with dysfunction of the endothelium being a major component of pathophysiology [11].

PM rich in metal components such as nickel $(\mathrm{Ni})$ has been linked to adverse cardiopulmonary effects in both cell and animal models [12-15]. We have previously documented that exposure to inhaled $\mathrm{Ni}$ nanoparticles or $\mathrm{PM}_{2.5}$ rich in Ni content can cause altered vasoreactivity, changes in heart rate and heart rate variability, induce adverse effects in bone marrow endothelial progenitor cells, and advanced the progression of atherosclerosis [16-20]. However due to the complexity and heterogeneity of $\mathrm{PM}_{2.5}$, identifying the exact component(s) and linking them to the observed effects remains a challenge. Although $\mathrm{Ni}$ is a minor mass component of $\mathrm{PM}_{2.5}$, we hypothesize that $\mathrm{Ni}$ is the driving constituent in $\mathrm{PM}_{2.5}$-induced cardiovascular disorders (CVD).

Our laboratory has previously reported that systemic inflammation and cardiovascular markers of atherosclerosis in residents of two Chinese cities, Jinchang (JC) and Zhangye (ZH), are linked to the $\mathrm{PM}_{2.5}$ compositions of each [21]. Despite similar $\mathrm{PM}_{2.5}$ concentrations (JC = $43.0 \mu \mathrm{g} / \mathrm{m}^{3}$ and $\mathrm{ZH}=45.5 \mu \mathrm{g} / \mathrm{m}^{3}$ ), JC, home to the second largest Ni refinery globally, had levels of $\mathrm{Ni}$, selenium $(\mathrm{Se})$, copper $(\mathrm{Cu})$, and arsenic (As) that were 76, 25, 17 , and 7 fold higher than in ZH, respectively [21]. Samples collected from these cities provide a unique PM composition profile to not only verify the critical role of $\mathrm{Ni}$ in $\mathrm{PM}_{2.5}$-associated CVD, but to also explore the potential mechanisms of action.

Ni found in PM has been reported to activate a chain of events, such as formation of reactive oxygen species (ROS), an up-regulation of the stress-inducible genes $[22,23]$, and can interference with electron transport pathways. Although there are numerous pathways that generate superoxide, two of particular importance involved with electron transport pathways are: Nicotinamide Adenine Dinucleotide Phosphate (NADPH) oxidase, and endothelial nitric oxide (eNOS) uncoupling. As such the generated superoxide directly impacts vascular function and is known to negatively affect vascular physiology via interaction between its molecular reduction into other more toxic forms of oxidative species (OS) and the vascular bed. The increase in superoxide production is one of the major contributors to the development of vascular dysfunction in cardiovascular disease states [24]. The majority of published works investigating adverse effects of PM on vascular function have been conducted utilizing larger conduit vessels, such as aorta $(>400 \mu \mathrm{m})$. However, the microcirculation is the primary site of vascular resistance and nutrient and waste exchange in the body. Perturbations in microvascular vasoreactivity can have profound impact on tissue perfusion, and ultimately homeostasis [24]. Since microcirculation takes place in the small resistance vessels (40-100 $\mu \mathrm{m}$ of lumen diameter) and regulates blood/oxygen flow and pressure to and from the tissues, they provide a good contrast to the larger, systematic conduit vessels, like the aorta. Hence, the aim of this study was two-fold: to use the $\mathrm{PM}_{2.5}$ samples collected from these cities to further explore the role of Ni found in PM and; to utilize this particulate to determine the underlying mechanism(s) of arteriolar function in the small resistance vessels of a mouse model following $\mathrm{PM}_{2.5}$ exposure. We hypothesized that exposure to $\mathrm{PM}_{2.5}$ rich in $\mathrm{Ni}$ alters arteriolar reactivity through mechanistic pathways involved in endothelium-dependent arteriolar dilation in the mesenteric arteries, of eNOS uncoupling and NADPH oxidase activation, leading to vascular ROS generation and vascular dysfunction.

\section{Results}

\section{Particle characterization}

The particle characterization and analysis is described by Niu et al. [21]. In brief, $\mathrm{PM}_{2.5}$ mass measurements were not significantly different between JC $\left(43.0 \pm 40.7 \mu \mathrm{g} / \mathrm{m}^{3}\right)$ and $\mathrm{ZH}\left(45.5 \pm 47.7 \mu \mathrm{g} / \mathrm{m}^{3}\right)$. The $\mathrm{PM}_{2.5}$ levels in both locations were approximately twice as high as the annual averages $\left(20.2 \pm 13.3 \mu \mathrm{g} / \mathrm{m}^{3}\right)$ observed in New York City [25]. However, the ambient level of Ni measured in the JC location $\left(204.8 \pm 268.6 \mathrm{ng} / \mathrm{m}^{3}\right)$ was 76 -fold higher than that measured in $\mathrm{ZH}\left(2.8 \pm 4.4 \mathrm{ng} / \mathrm{m}^{3}\right)$. The sulfate form of the metals were selected for spiking since sulfur was high in the PM samples and also because sulfates are soluble and hence they are good candidates to investigate as drivers of the observed effects.

\section{Bronchoalveolar Lavage Fluid (BALF) characterization}

Protein leakage (Figure 1A), neutrophil infiltration (Figure 1B), and cell count (Figure 1C), results from BALF analysis from a single aspiration dose of $50 \mu \mathrm{g} /$ mouse $(1 \mathrm{mg} / \mathrm{ml})$ revealed pulmonary inflammation. Specifically, protein leakage from mice treated with $\mathrm{ZH}$ was significantly higher than control; however, JC caused the greatest pulmonary inflammation. Particles from $\mathrm{ZH}$ spiked with one or all of the four metals found in the same concentrations as seen in the JC sample (As, $\mathrm{Se}, \mathrm{Cu}$, and $\mathrm{Ni}$ ) demonstrated an increase in protein leakage (Figure 1A). Although there could be countless combinations of metals that could be studied, for the purposes of this study we decided to focus on the one that had the greatest inflammatory effects. Specifically, $\mathrm{Ni}$ was of greatest interest due to previous 


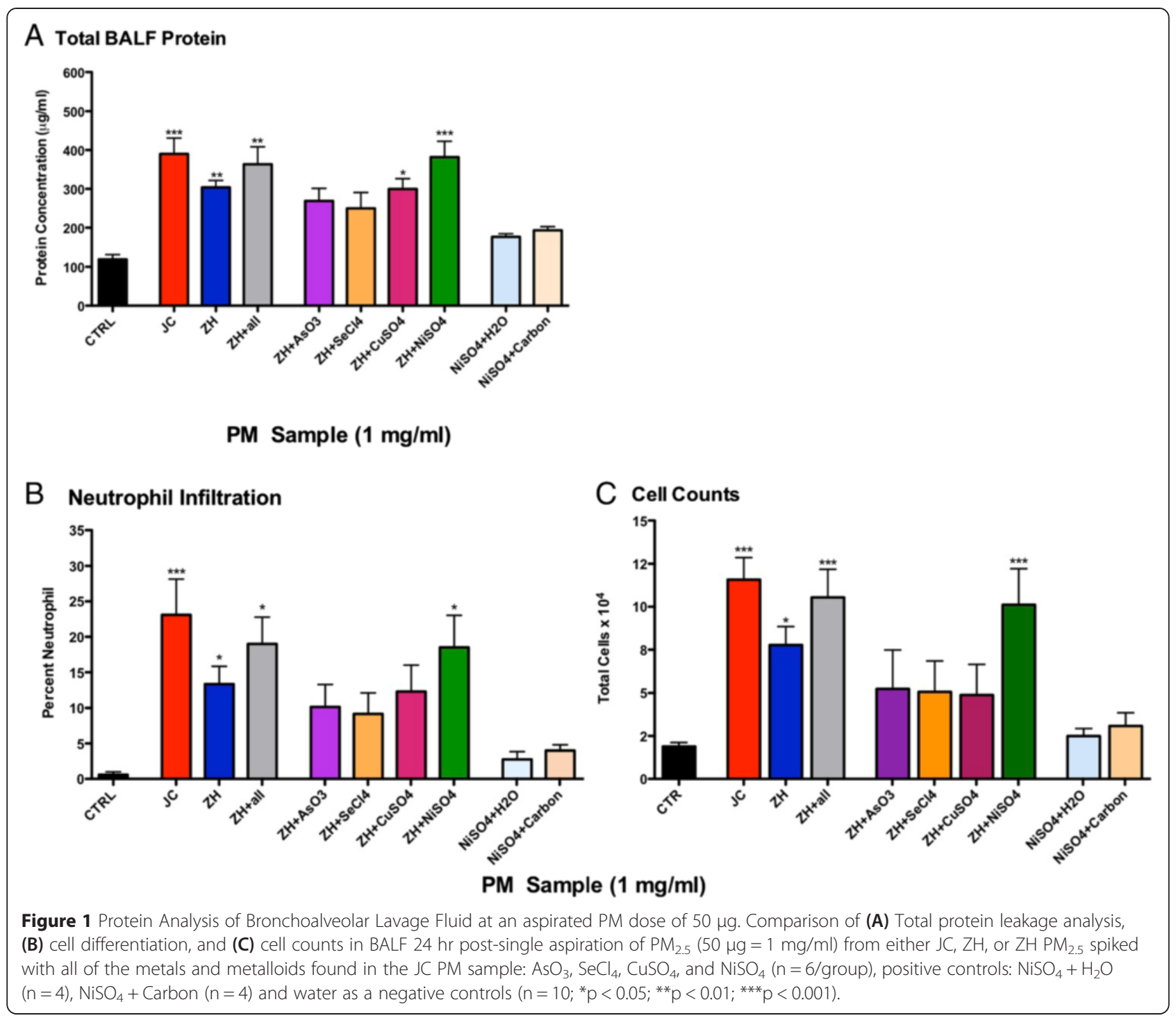

work [21] and the high inflammatory response observed in the $\mathrm{ZH}+\mathrm{NiSO}_{4} \mathrm{PM}$ treatment group. $\mathrm{ZH}$ PM spiked with all four metals $(\mathrm{ZH}+$ all $)$ demonstrated inflammatory levels close to that of exhibited by JC PM. Our lab has historically utilized a dose of $50 \mu \mathrm{g} / \mathrm{mouse}(1 \mathrm{mg} / \mathrm{ml})$ for aspiration studies, which yielded a reasonable percentage of neutrophil infiltration per standardized and acceptable aspiration methodology [26]. However, these particles from China caused an approximate 25 percent neutrophil infiltration (Figure 1B) and this dose was deemed too high of an inflammatory state for the animal to obtain accurate results in a repeated aspiration study. We therefore, conducted a dose response study and continued experiments at the dose level of $25 \mu \mathrm{g} / \mathrm{mouse}(0.5 \mathrm{mg} / \mathrm{ml}$; Figure 2). A single and repeated aspiration model using PM combinations of $\mathrm{JC}, \mathrm{ZH}$, and $\mathrm{ZH}+\mathrm{NiSO}_{4}(0.5 \mathrm{mg} / \mathrm{ml})$ demonstrated significantly higher inflammation in the JC group in comparison to control (Figure 2). Although it is possible that $\mathrm{Ni}$ was not the only driver of the observed response, the $\mathrm{ZH}+\mathrm{NiSO}_{4}$ group emulated similar results as those of the JC group. No differences were seen in the one-time control versus the six-time exposure control.

\section{Serum markers indicative of inflammation and vascular dysfunction}

Serum from mice treated with $\mathrm{JC}, \mathrm{ZH}$ and $\mathrm{ZH}+\mathrm{NiSO}_{4}$ had significantly higher IL-10 concentrations as compared to the control in the respected exposure duration (Figure 3A). Further VEGF was significantly greater in JC and $\mathrm{ZH}+\mathrm{NiSO}_{4}$ in both exposure durations (Figure 3B). Statistically higher levels of TNF- $\alpha$ were detected in the $\mathrm{ZH}+\mathrm{NiSO}_{4}$ in comparison to $\mathrm{ZH}$ alone Figure 3E). No statistical differences were detected for IL-13, IL-6, CSF, and MCP-1 (Figure 3C,D,F,G). 


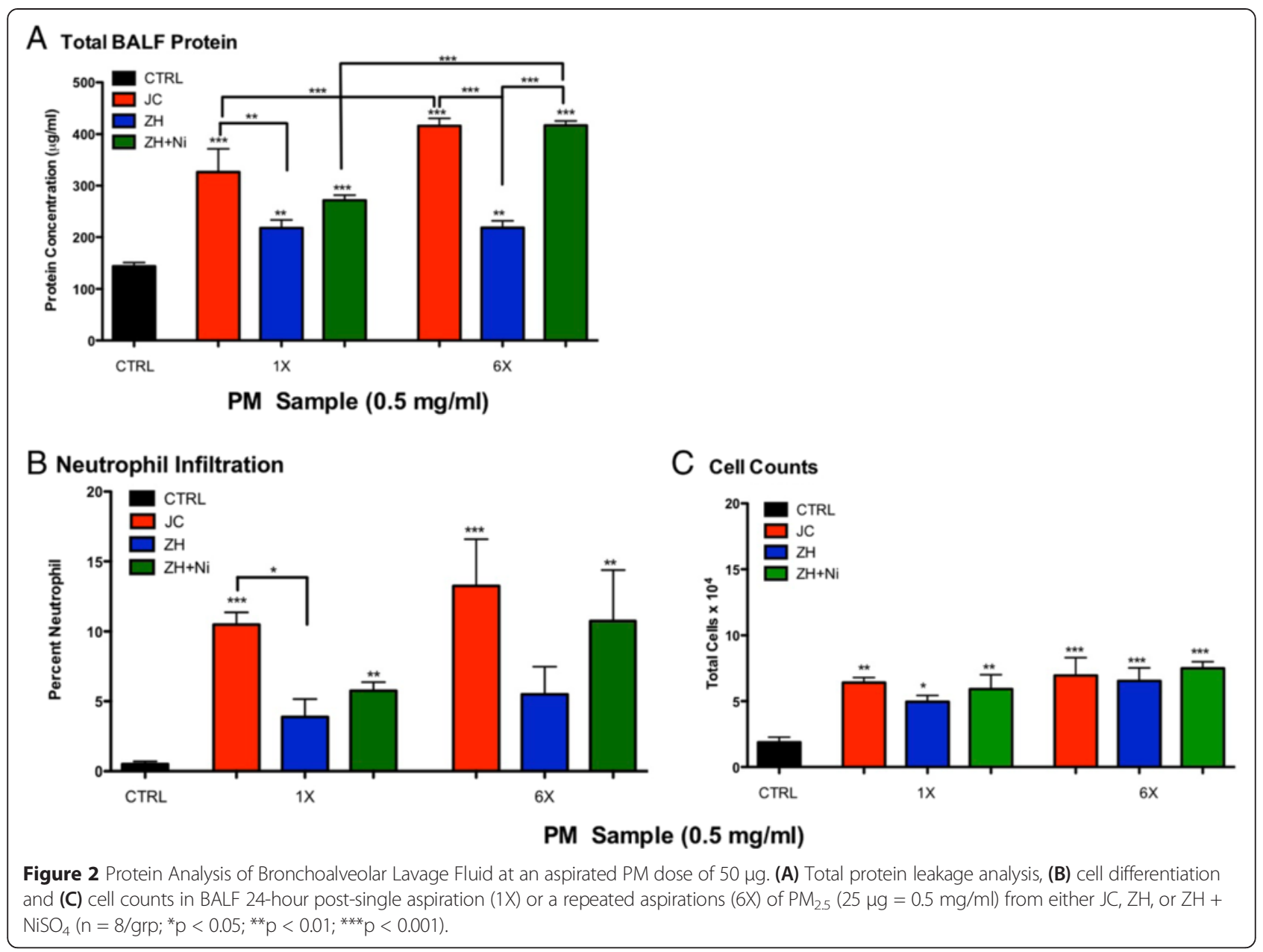

No significant differences were detected at the one time point exposure compared to the respected controls. There were however, significantly higher concentrations of NO discovered between repeated exposure groups (Figure 4). More specifically, repeated exposures induced a significant decrease in NO concentration in the JC and the $\mathrm{ZH}+\mathrm{NiSO}_{4}$ samples as compared to controls. There was also a time dependent difference indicated by a significantly lower NO concentration in the JC repeated group compared to the one-time exposure JC group.

\section{PM-induced vascular response}

Since constrictive responses to $120 \mathrm{mM} \mathrm{KCl}$ did not differ significantly among groups, agonist-induced responses were standardized using the $120 \mathrm{mM} \mathrm{KCl}$ responses. No significant differences were observed in the percentage of PE-induced pre-contraction between all groups and were therefore used to normalize vasodialtor (e.g. ACh, SNP) mediated responses. Results from repeated aspirations using $\mathrm{PM}$ from $\mathrm{JC}, \mathrm{ZH}$, and $\mathrm{ZH}+\mathrm{NiSO}_{4}(0.5 \mathrm{mg} / \mathrm{ml})$ indicated no statistical differences between groups for percent
PE-induced contraction, SNP-induced relaxation or the half maximal effective concentration halfway between the baseline and maximum response values, respectively (Table 1 and Figure 5). Differences were seen in all groups when comparing maximum ACh-induced percent relaxation to controls however, only significant differences were seen in the $\mathrm{JC}$ and the $\mathrm{ZH}+\mathrm{NiSO}_{4}$. In the presence of various inhibitors vascular function was improved (Figure 6). Greatest improvement was seen in the presence of NADPH oxidase inhibitor, VAS2780. ODQ and NAC showed no differences in either the treatment groups or in the control group (data not shown).

\section{Quantitative real time RT-PCR analyses}

Quantitative real time RT-PCR results indicated a significantly higher mRNA expression of $T N F-\alpha$ in mice treated with $\mathrm{JC}$ and $\mathrm{ZH}+\mathrm{NiSO}_{4} \mathrm{PM}$ as compared to control mice as well as when compared between exposure groups and exposure frequency (Figure 7A). IL-6 expression was also significantly elevated in mice that received $\mathrm{JC}$ and $\mathrm{ZH}+$ $\mathrm{NiSO}_{4} \mathrm{PM}_{2.5}$ aspirations when compared to the controls 

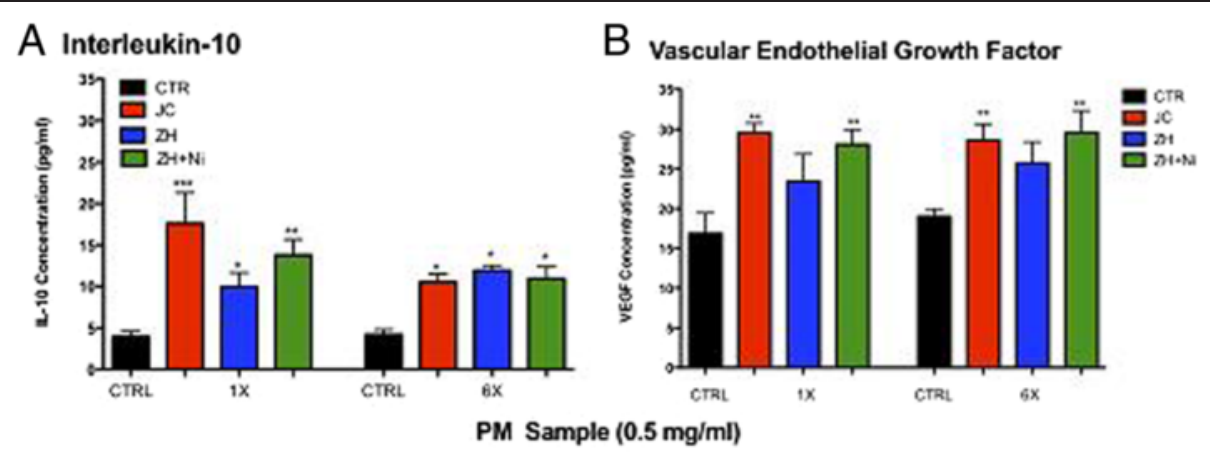

C Interleukin-13

D Interleukin-6
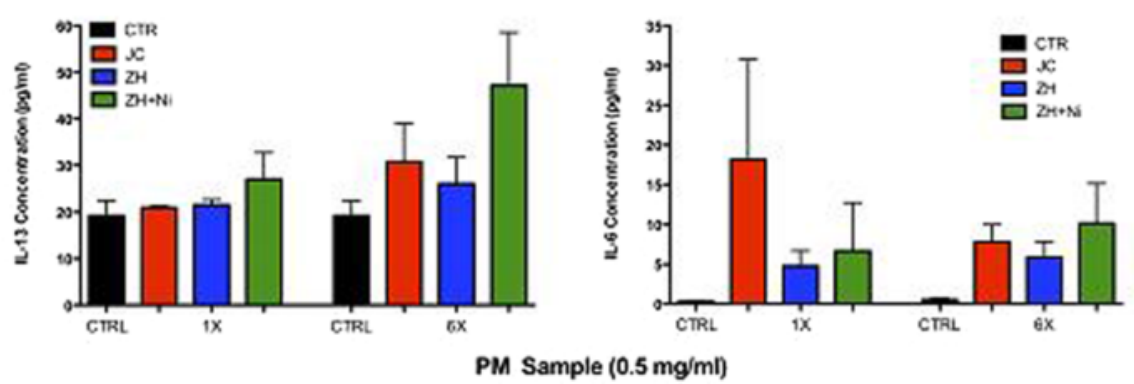

E Tumor Necrosis Factor-a

PM Sample (0.5 mg/ml)

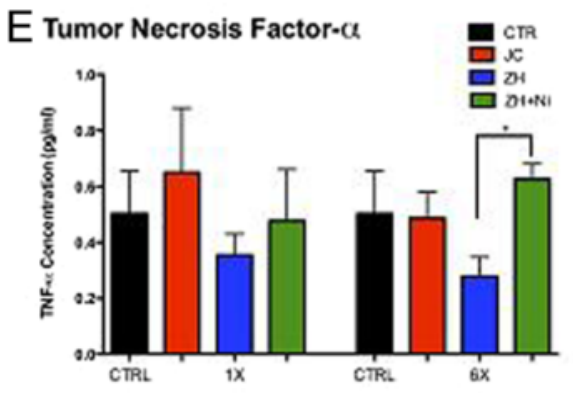

F colony Stimulating Factor

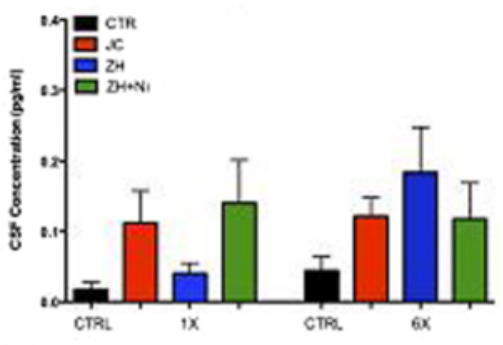

PM Sample (0.5 mg/ml)

\section{G Monocyte Chemotactic Protein-1}

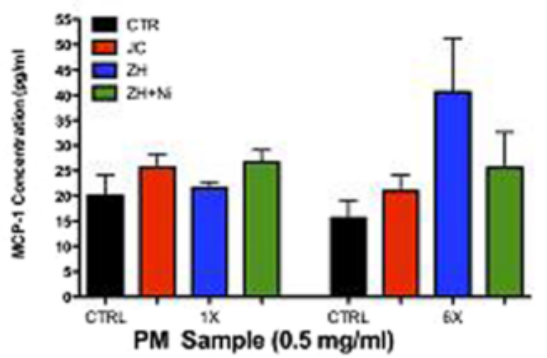

Figure 3 Inflammatory Markers in Serum (A) IL-10, (B) VEGF, (C) IL-13, (D) IL-6, (E) TNF-a, (F) CSF, (G) MCP-1. Serum from mice exposed to either single (1X) or a repeated aspirations (6X) with $(25 \mu \mathrm{g}=0.5 \mathrm{mg} / \mathrm{ml})$ from JC, $\mathrm{ZH}$ or $\mathrm{ZH}+\mathrm{NiSO}_{4}\left(\mathrm{n}=6 / \mathrm{grp} ;{ }^{*} \mathrm{p}<0.05 ;{ }^{* *} \mathrm{p}<0.01\right.$; $\left.{ }^{* * *} \mathrm{p}<0.001\right)$. Significance was determined by comparison of all groups and Error bar represents SEM.

as well as when compared between exposure and exposure duration (Figure 7B). Both total SOD and MMP-9 expression was significantly higher in the $\mathrm{JC}$ and $\mathrm{ZH} \mathrm{PM}_{2.5}$ spiked with $\mathrm{NiSO}_{4}$ in the $1 \mathrm{X}$ and $6 \mathrm{X}$ treated groups (Figure $7 \mathrm{C}$ and D). Significantly higher mRNA expression of Nos3 was seen in the $1 \mathrm{X}$ with $\mathrm{JC}$ and $\mathrm{ZH}+\mathrm{NiSO}_{4}$ groups in comparison to those treated 6X and the control group (Figure 7E). NADPH Oxidase (NOX4) was significantly higher in the $6 \mathrm{X}$ aspirated group of $\mathrm{JC}$ and $\mathrm{ZH}+\mathrm{NiSO}_{4}$ as compared the single aspirated groups (Figure 7F). 


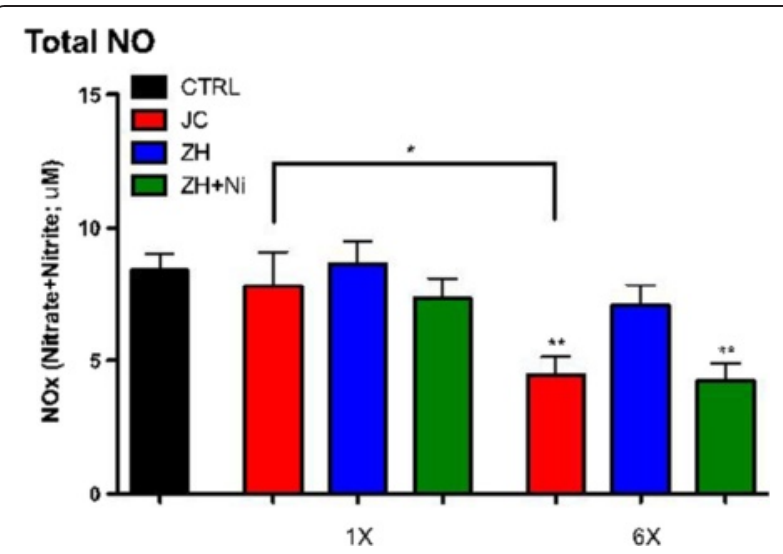

Figure 4 Total NO Measurement in Serum. Serum was collected from mice aspirated with either a single (1X) or a repeated aspirations (6X) with $(25 \mu \mathrm{g}=0.5 \mathrm{mg} / \mathrm{ml})$. *indicates a significant difference between the exposure and control group as determined by one-way Student $t$-Test $\left({ }^{*} p<0.05 ;{ }^{* *} p<0.01 ; n=6 / g r p\right)$.

\section{Discussion}

Lung inflammation has been identified as a major concern from inhalation exposure of PM, however, this study attempted to focus more so on systemic inflammatory changes due to PM exposure. To our knowledge, this is the first study to demonstrate systemic microvascular effects of pulmonary exposure to unique particulate collected from two locations comparable in $\mathrm{PM}_{2.5}$ concentration but one being uniquely higher in metal and metalloid content. Furthermore, this study demonstrates that pulmonary exposure can result in acute microvascular dysfunction.
Systemic inflammation plays a central role in the development of CVD, especially development/progression of atherosclerosis, including leukocyte recruitment, endothelial activation and dysfunction, leading to plaque formation and rupture [27]. Previously, our group has shown an increase in inflammatory cytokine and chemokine (Il- $1 \alpha$, TNF- $\alpha$, Mip-2, and Ccl2) mRNA expression levels in lavaged lung tissue of mice exposed to various concentrations of $\mathrm{Ni}$ nanoparticles [28]. In our study, various inflammatory markers were assessed in BALF, serum, and in mesenteric arteries from mice exposed to PM collected from two locations in China and also PM spiked with Ni. The significant increase detected in total protein levels and neutrophil infiltration in BALF demonstrated these particles were capable of inducing pulmonary inflammation after each exposure (Figures 1 and 2). Further, this is in line with various studies that have shown that inhaled PM, which deposits throughout the respiratory tract, can induce both oxidative stress and inflammation [29,30]. The metal components in PM can also induce OS via Fenton reactions. In turn, OS and inflammatory responses may further increase the risk of vascular damage [31,32]. Our findings demonstrate that there is a dose dependent change seen in the immune response in the lung that may contribute to the systemic inflammatory processes, as indicated in the increases in BALF protein levels and the associated inflammatory markers in serum, such as increases in IL-10, VEGF, (Figure 3A,B respectively).

Many studies report that VEGF induces adhesion molecules during states of inflammation [33]. Since over-

Table 1 Gansu particle aspirations in male FVB/N mice $(0.25 \mu \mathrm{g})$

\begin{tabular}{|c|c|c|c|c|}
\hline Gansu PM repeated aspiration & $\mathrm{H}_{2} \mathrm{O}(\mathrm{n})$ & $J C(n)$ & $\mathrm{ZH}(\mathrm{n})$ & $\mathrm{ZH}+\mathrm{NiSO}_{4}(\mathrm{n})$ \\
\hline PE Max contraction $(\% \pm S E)$ & $100 \pm 2.59$ & $100.2 \pm 5.84$ & $98.7 \pm 2.71$ & $99.8 \pm 7.17$ \\
\hline $\log E C_{50}(M \pm S E)$ & $-6.04 \pm 0.17(8)$ & $-6.13 \pm 0.08(14)$ & $-6.00 \pm 0.04(6)$ & $-6.32 \pm 0.12(16)$ \\
\hline SNP Max relaxation $(\% \pm S E)$ & $1.96 \pm 12.4$ & $14.11 \pm 7.73$ & $5.24 \pm 6.18$ & $18.8 \pm 8.59$ \\
\hline $\log E_{50}(M \pm S E)$ & $-7.05 \pm 0.15$ & $-7.03 \pm 0.25$ & $-6.69 \pm 0.14$ & $-7.23 \pm 0.28$ \\
\hline $\mathrm{ACh}$ Max relaxation $(\% \pm \mathrm{SE})$ & $1.74 \pm 3.08$ & $33.0 \pm 3.16^{* * *}$ & $8.84 \pm 6.29$ & $23.6 \pm 3.27^{* * *}$ \\
\hline $\log \mathrm{ED}_{50}(\mathrm{M} \pm \mathrm{SE})$ & $-7.00 \pm 0.07$ & $-6.65 \pm 0.10$ & $-6.82 \pm 0.15$ & $-6.47 \pm 0.08$ \\
\hline
\end{tabular}

Above data expressed as Mean \pm SEM. Significant differences determined by comparison to $\mathrm{H}_{2} \mathrm{O}$ controls; ${ }^{* *} \mathrm{p}<0.001$.

Apocynin

\begin{tabular}{|c|c|c|c|c|}
\hline ACh Max relaxation $(\% \pm \mathrm{SE})$ & NA & $7.72 \pm 4.30^{* *}$ & NA & $15.0 \pm 6.63$ \\
\hline $\log E D_{50}(M \pm S E)$ & & $-6.83 \pm 0.11(5)$ & & $-6.47 \pm 0.13(5)$ \\
\hline \multicolumn{5}{|l|}{ LNAME } \\
\hline ACh Max relaxation $(\% \pm S E)$ & NA & $16.3 \pm 7.51^{*}$ & NA & $12.2 \pm 7.97$ \\
\hline $\log _{E D}{ }_{50}(M \pm S E)$ & & $-6.72 \pm 0.18(5)$ & & $-6.63 \pm 0.16(5)$ \\
\hline \multicolumn{5}{|l|}{ VAS2870 } \\
\hline ACh Max relaxation $(\% \pm S E)$ & NA & $0.44 \pm 4.26^{* * *}$ & NA & $0.11 \pm 5.53^{* * *}$ \\
\hline $\log _{E D}{ }_{50}(M \pm S E)$ & & $-6.93 \pm 0.11(5)$ & & $-6.70 \pm 0.11(5)$ \\
\hline
\end{tabular}




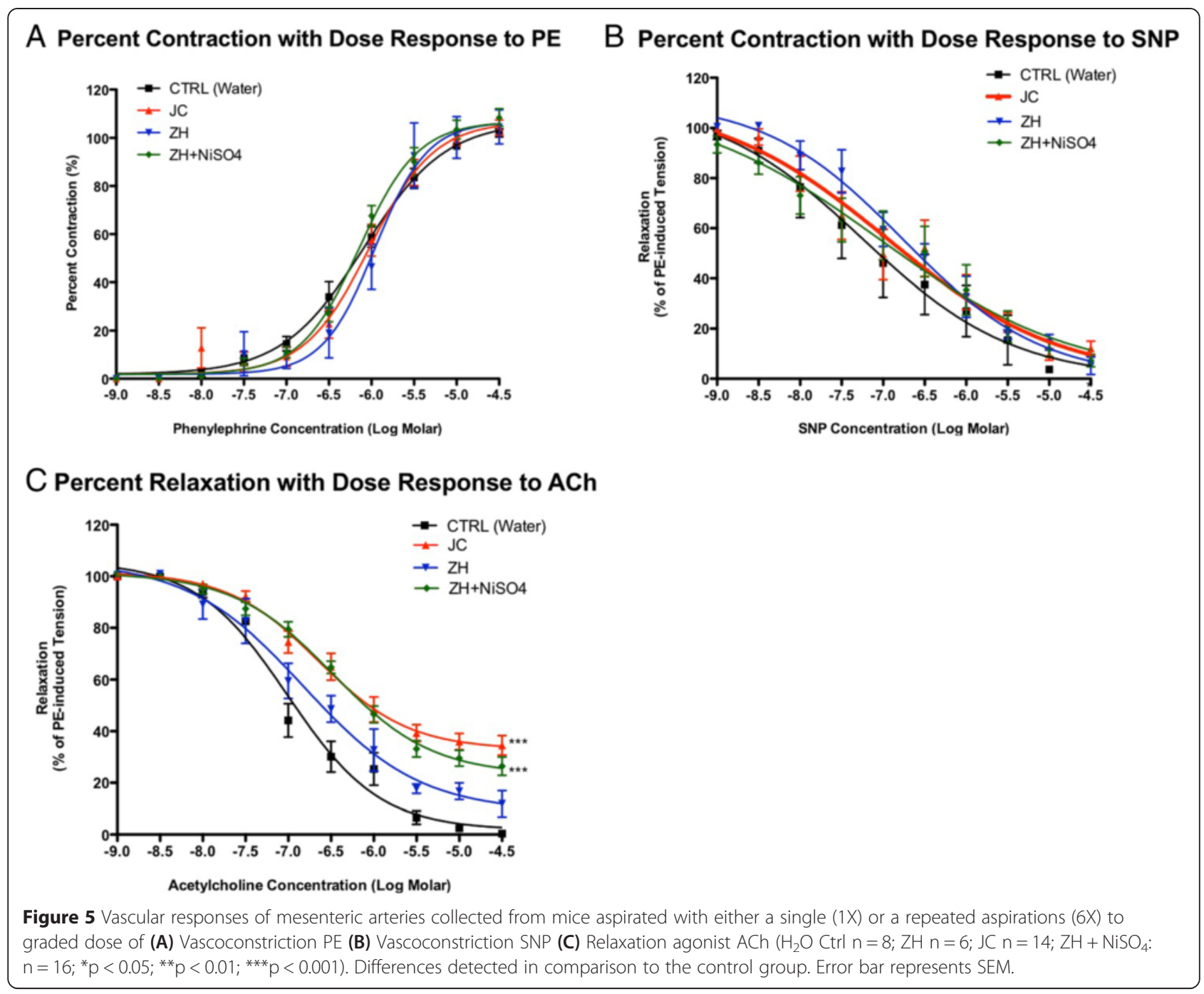

A JC Percent Relaxation with Dose Response to ACh with Inhibitors

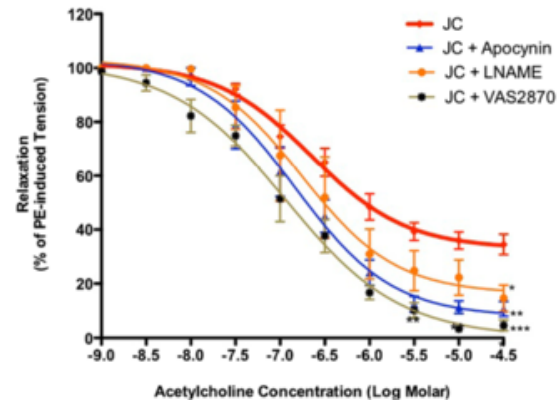

B ZH Percent Relaxation with Dose Response to ACh with Inhibitors

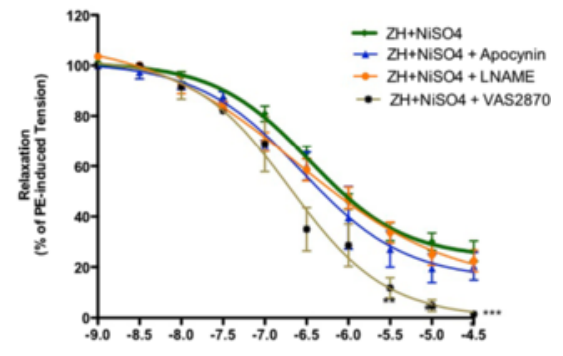

Acotycholine Concentration (Log Molar)

Figure 6 Vascular responses of mesenteric arteries collected from mice aspirated with either a single (1X) or a repeated exposures (6X) to graded dose of (A) $\mathrm{JC}$ or (B) $\mathrm{ZH}+\mathrm{NiSO}_{4}$ and subsequently treated with various inhibitors. Differences detected in comparison to the control group and each respected group prior to inhibitor incubation $\left(\mathrm{H}_{2} \mathrm{O} \mathrm{Ctrl} n=8 ; \mathrm{ZH} \mathrm{n}=6 ; \mathrm{JC} n=14 ; \mathrm{ZH}+\mathrm{NiSO}_{4} \mathrm{n}=16 ; n=5-6 /\right.$ inhibitor groups; ${ }^{*} p<0.05$; $\left.{ }^{* *} \mathrm{p}<0.01 ;{ }^{* * *} \mathrm{p}<0.001\right)$. Error bar represents SEM. 


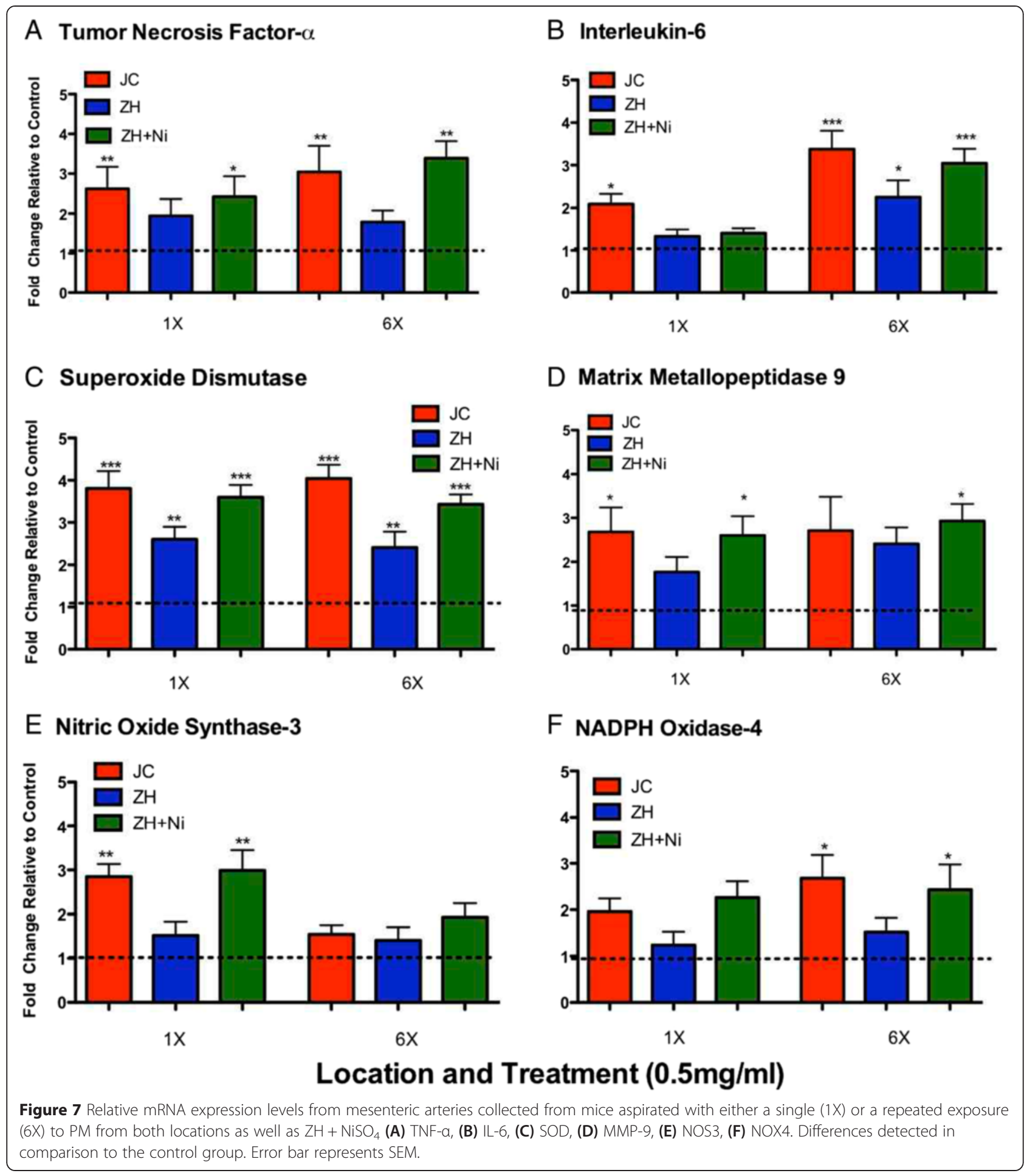

expression of circulating VEGF, in combination with defective VEGF receptors, can contribute to vascular disease by promotion of leaky vessels and prevention of EPC mobilization [34,35], high levels of PM-induced VEGF were expected in our samples. Our findings confirmed this hypothesis. The PM concentrations used in this study coupled with the Ni content may have contributed to the significantly higher VEGF concentrations in $\mathrm{JC}$ and $\mathrm{ZH}+\mathrm{NiSO}_{4}$ groups as compared to control over the three-week exposure period. The fact that these changes were not observed in the $\mathrm{ZH}$ group, as compared to the control, may implicate $\mathrm{Ni}$ as the main 
culprit. The increase in VEGF concentration that we detected is supported by previous reports that the expression of VEGF can be mediated by metal induced hypoxia as well as direct interactions with various soluble $\mathrm{Ni}$ compounds [36]. Hypoxic conditions have also been documented to produce VEGF in order to stimulate angiogenesis and vascular remodeling [37]. Taken together, this indicates that perhaps the PM samples that were high in soluble $\mathrm{Ni}$ induced hypoxic conditions, leading to an increase in VEGF in serum as an attempt to stimulate vascular remodeling via angiogenesis.

Traditionally, matrix metalloproteinases (MMPs) have been of particular interest in their role in lung remodeling, and have been found to be central to various airway pathologies [14]. However, elevated serum levels of MMP-9 have also been identified as a novel predictor of cardiovascular mortality. During high states of oxidative stress, as evidenced by an increase in Peroxynitrite $\left(\mathrm{ONOO}^{-}\right)$, the latent MMPs are activated in serum, induce vascular remodeling, and can increase expression in the vascular tissues [38]. Upregulation of MMP-9 after exposure to metals, such as vehicular emissions exposures, has been documented [39]. Specifically, Lund et al. [39] reported that a 7-week inhalation exposure to gasoline engine emissions induced elevations in aortic mRNA expression of various MMPs (ie. $M M P-3, M M P$ 7, and MMP-9) in $\mathrm{ApoE}^{-1-}$ mice. A later study by Lund et al. [40] reported a 7-day gasoline exhaust exposure induced upregulation of vascular ROS [measured as Thiobarbituric acid reactive substances (TBARS)], as well as an immediate activation of MMP-9, followed by a significant increase in transcriptional MMP-9. Our results of MMP-9 measured in both serum and as mesenteric mRNA expression were in accordance with these findings. Both single and repeated aspirations of Gansu PM, high in PM concentration and metal content (JC and $\mathrm{ZH}+\mathrm{NiSO}_{4}$ ), resulted in a significant unregulation of MMP-9 when compared to $\mathrm{ZH}$ alone as well as to control samples.

Super oxide dismutase (SOD) is a pivotal antioxidant enzyme in vascular tissue that serves to convert superoxide anions into oxygen and hydrogen peroxide. Our study found that both short and longer-term aspirations of PM collected from Gansu Province resulted in significant increases in total SOD mRNA expression. Specifically, we found greater differences were detected in arteries from mice treated with all groups of PM and at both exposure durations when compared to control (Figure 7C). Similarly, mRNA expression of eNOS was significantly increased in the $\mathrm{JC}$ and $\mathrm{ZH}+\mathrm{NiSO}_{4}$ group as compared to the single exposure control, which is not seen in the repeated exposure samples. In various vascular diseases, endothelial dysfunction is characterized by a decrease in NO bioactivity, with a concomitant increase in superoxide formation, despite the observation that eNOS mRNA were maintained or even increased. For example, eNOS protein expression was found to be increased, yet endothelial function was impaired in response to hyperglycemia, high blood pressure, or advanced age $[41,42]$. This increase in SOD and eNOS gene expression observed may be an attempt to protect vascular tissue from increased production of ROS generated by PMinduced uncoupling of eNOS. It is also possible that other sources of NOS (e.g. iNOS) could be contributing to these observed vascular effects and therefore future studies will explore these pathways.

The most significant finding of this study is the particle induced vascular response. Vascular oxidative stress can result from a plethora of pathways, such as NADPH oxidase, myeloperoxidase activity, xanthine oxidase, lipoxygenases, eNOS uncoupling, and the dysfunctional mitochondrial respiratory chain and lend to a variety of pathologies $[43,44]$. Although these pathways may operate in concert, in our study, we have demonstrated that exposures of PM from the two locations in China initiated an increase of NADPH oxidase derived ROS as indicated by the VAS2870 inhibition of NADPH oxidase (Figure 6A and B). Our results complement those from other ex vivo animal studies reporting that inhalation and aspiration exposure of environmental and other model particles are associated with both inflammatory and OS outcomes that have been shown to contribute to the impairment of endothelial function [12,45-50,51]. Impaired vascular response can be either due to a lack of nitric oxide $(\mathrm{NO})$ or a dysfunction of the smooth muscle cell layer. Usage of Nox2 knockout mice could have been a good tool to utilize in order to confirm the dependence on this pathway as per Kampfrath et al. [52], however, the limited amount of available particulate posed a limitation to further exposures in vivo. We measured the total levels of $\mathrm{NO}$ as a marker vascular function and our results indicated significant lower levels of total $\mathrm{NO}$ in groups treated with repeated doses of JC and $\mathrm{ZH}+\mathrm{NiSO}_{4}$ as compared to control and single exposures (Figure 4). We further investigated the role of $\mathrm{NO}$ and vascular function using an endothelial independent vasodilator, specifically, SNP in addition to ACh. However, since there was no difference in SNPinduced relaxation, it is most likely that the endothelium was most likely the target of damage. L-NAME slightly augmented ACh-induced relaxation, but did not completely assist in ACh relaxation, as is seen with the other inhibitors (Figure 6A and B). This can be explained because ACh-induced dilation could be mediated by NO, as well as other mediators such as Endothelium-Derived Hyperpolarizing Factor (EDHF). As such, NO-mediated contribution could be blocked by L-NAME, the remaining portion of the response may be mediated by non-NO 
mediator(s) and therefore, that contribution is not sensitive to L-NAME. Given our results from the vascular study, we conclude that PM-induced eNOS uncoupling and NADPH oxidase activation could be working in combination.

It is important to note that aspiration exposures are not a biologically relevant PM delivery method, however, this technique allows us to explore the individual components of PM as well as the mechanisms of PM-induced injury. Specifically, various studies identify oropharyngeal aspiration as an acceptable exposure methodology to deliver ambient PM collected from various sampling sites [22,43] to study animals when inhalation exposure is not possible or difficult to perform. The weekly dose delivered to mice in our study ( $100 \mu \mathrm{g} / \mathrm{mouse})$ is comparable to the ambient $\mathrm{PM}_{2.5}$ concentration of $100-700 \mu \mathrm{g} / \mathrm{m}^{3}$, which is similar to the peak ambient $\mathrm{PM}_{2.5}$ concentration recently measured in Beijing [53]. We assume a 40\% deposition efficiency of the particulate in the mouse lung over a one-week period of aspiration exposures, which equates to an exposure of approximately $96 \mu \mathrm{g} /$ week. Similarly, the total PM dose for our 3-week exposure was $300 \mu \mathrm{g}$. This dose is only 5 times higher than the total PM dose described by Zhang and colleagues [53], where the average CAPs concentration was $68 \mu \mathrm{g} / \mathrm{m}^{3}$ with 15 weeks of exposure. Therefore, we believe that our exposure was not only similar to that in the Zhang et al. study but it also reflected the current real world exposure scenario in places in the world, like China. It is also difficult to justify that the changes we report were induced by solely the Ni component of the JC PM sample. It is understood that there could have been many combinations of the four elements, present in the JC PM that we could have tested; however, the preliminary BALF analysis pinpointed $\mathrm{Ni}$ as the main contributor to pulmonary inflammation. Additionally, it would have been ideal if these samples could have been spiked with both $\mathrm{Ni}$ sulfate and $\mathrm{Ni}$ oxide to address the contribution of soluble versus insoluble nickel. However, work that has been produced from our laboratory we explore the contribution of sulfate compared to oxide and reported that Ni sulfate was more toxic than the oxide form [28]. Also, the limited quantity of available particulate made it difficult to perform extensive repeated exposures. While the serum measurements of the cytokines in this study indicated systemic inflammation, we were unable to make similar measurements in BALF. We did not measure the expressions of various adhesion molecules such as ICAM and VCAM, because the expressions of these genes were not significantly different in our human exposure population study [21]. Further, information on each specific SOD would be helpful in better understanding the effects of PM-induced vascular damage. As such, future studies will be focused discerning the differences in the expression of the various SODs. Further, our data is limited to fairly short exposure durations and only 24 hours post last exposure endpoints were evaluated. Longer exposures, dose, elemental combinations, and time course of responses would also help to delineate the development of PM induced vascular dysfunction.

\section{Conclusion}

This study suggests that pulmonary, as well as, vascular responses can be driven by specific components of $\mathrm{PM}_{2.5}$. Even short-term exposure to PM can induce an acute systemic inflammatory response and trigger endothelial damage and vascular dysfunction. Our findings of endothelial dysfunction induced by this unique $\mathrm{PM}_{2.5}$ from Gansu Province suggest that the adverse cardiovascular effects observed are linked specifically to Ni. We report that Ni could induce an inflammatory response, alter endothelium function, and hence, elucidate vascular effects. In turn, this may adversely affect the endothelial layer thereby increasing circulating vascular mediators (inflammatory cytokines and vascular adhesion molecules) and cause an increase in vascular tone, a decrease in arterial compliance, and increases central arterial pressure, resulting in increases in left ventricular workload. These makers of vasculature impairment (e.g. arterial noncompliance or stiffening) can ultimately decrease the blood volume to the tissues increasing risk for stroke or a variety of other CVDs.

\section{Methods \\ Animals}

Male FVB/N mice, (12 weeks old, body weight 20-25 g) were obtained from Taconic Farms (Germantown, NY) and housed in an Association for Assessment and Accreditation of Laboratory Animal Care (AAALAC) accredited facility in Tuxedo, NY. Animals were given a two-week acclimation period, kept on normal $12 \mathrm{~h}$ light/ dark cycles and received food and water ad labium, except during the exposure period. All procedures were conducted in compliance with New York University's guidelines for ethical animal research.

\section{$\mathrm{PM}_{2.5}$ sample collection and characterization}

Details of the PM collection process and location are described elsewhere [31]. In brief, the particles were collected simultaneously from two large adjacent cities in Gansu Province, China from March 6th 2009-March 26th 2010: Jinchang (JC), home to the second largest nickel refinery globally, and Zhangye (ZH), an upwind city 250 miles away. Teflon filters with $\mathrm{PM}_{2.5}$ sharp-cut cyclone inlets were used to collect daily samples in both locations. Mass concentrations (obtained gravimetrically) and filter analyses for 35 elements (X-ray fluorescence spectroscopy; XRF, Model EX6600AF, Jordan Valley and spectral software XRF2000v3.1, U.S. EPA and ManTech Environmental Technology, Inc.) were conducted once 
all samples were collected as per Maciejczyk et al [20]. Field blanks consisting of identical filter substrate were left open to ambient air and passively collected particles $(\mathrm{n}=30)$. National Institutes of Standards and Technology) standard PM reference 1648 samples, and field blanks were incorporated for quality assurance.

\section{PM extraction}

Filters were pre-wet with $70 \%$ ethanol and then sonicated in ice-cooled water for $1 \mathrm{hr}$. The extracted material was frozen, concentrated using lyophilization, and weighed to determine the extraction efficiency. Recovery of the PM averaged $80 \%$. Extracts were reconstituted in sterile milliQ water to a final concentration of $1 \mathrm{mg} / \mathrm{ml}$ and stored at $-80^{\circ} \mathrm{C}$. Prior to use, the reconstituted extract was sonicated for 20 minutes and vortexed to disperse particle agglomerates.

\section{Exposure}

An oropharyngeal aspiration technique [26] was used to disperse PM into the lungs of mice. In brief, mice were anesthetized with $0.5 \%$ Isoflurane and given a $50 \mu \mathrm{l}$ bolus of aqueous suspension of $\mathrm{PM}_{2.5}$ extract $(1 \mathrm{mg} / \mathrm{ml})$ from $\mathrm{JC}, \mathrm{ZH}$ or $\mathrm{ZH}$ spiked with one of the following elements at the same concentrations found in the JC PM $\left(\mathrm{NiSO}_{4}=4.76 ; \quad \mathrm{AsO}_{3}=2.36 ; \quad \mathrm{SeCl}_{4}=0.24 ; \quad \mathrm{CuSO}_{4}=\right.$ $2.43 \mu \mathrm{g} / \mathrm{mg} ; \mathrm{n}=6 / \mathrm{grp})$ or water control $(\mathrm{n}=10)$ via a single oropharyngeal aspiration. In order to understand if synergistic effects were a result from the actual particulate plus $\mathrm{Ni}$ mixture or from $\mathrm{Ni}+$ an inert particle (carbon) other control groups, $\mathrm{NiSO}_{4}+\mathrm{H}_{2} \mathrm{O}$ and $\mathrm{NiSO}_{4}+$ Carbon, were used as negative controls $(n=4 / g r p)$. Pulmonary inflammation in BALF was evaluated in the aforementioned groups. PM spiked with Ni demonstrated the most pulmonary inflammation (Figure 1) and therefore, to further study the effects of $\mathrm{Ni}$ within this unique PM sample, additional groups of mice received a single or repeated (twice a wk for 3 wks) aspirated dose $(50 \mu \mathrm{l} @ 0.5 \mathrm{mg} /$ $\mathrm{ml}$ ) of $\mathrm{JC}, \mathrm{ZH}$ or $\mathrm{PM}_{2.5}$ from $\mathrm{ZH}$ that was spiked with $\mathrm{Ni}\left(\mathrm{ZH}+\mathrm{NiSO}_{4} ; \mathrm{n}=8\right.$ /location) or water control $(\mathrm{n}=8)$. See Table 2 for a summary of the exposure groups. At the termination of the study, mice were euthanized, and organs were harvested and placed in liquid nitrogen. Fresh preparation of mesenteric arteries were collected and immediately placed in cold physiological salt solution.

\section{BALF assays}

BALF fluid analysis was performed as previously described [8]. In brief, the trachea was cannulated and the lungs lavaged twice with $1.2 \mathrm{ml}$ of phosphate buffered saline without calcium and magnesium (PBS, Invitrogen, Carlsbad, CA, USA). Harvested fluid was used to examine cell counts, cell differential and total protein levels. For cell differentials, an aliquot of lavage fluid was prepared using cytospin (Shandon, Southern Products, UK) with subsequent Hemacolor ${ }^{\circ}$ staining (EM Science, Gibbstown, NJ, USA). Percentage of neutrophil population was enumerated by counting 100 total cells. The remaining lavage fluid was centrifuged at $400 \mathrm{~g}$ for $10 \mathrm{~min}$. The supernatant was analyzed for total protein levels using bovine serum albumin as a standard (BioRad, Hercules, CA, USA). All BALF assays were analyzed in duplicate.

\section{Markers of inflammation and vascular function in serum}

Ten markers of inflammatory and vascular function were analyzed in serum using an ultra sensitive electrochemiluminescence method, Meso-Scale Discovery Multi-Array technology (MSD, Gaithersburg, MD). A custom MSD cytokine panel was designed with the ability to detect seven markers (IL-6, -10, -13, MCP-1, MIP-1, MIP-1 $\beta$, and TNF- $\alpha$ CSF, MMP-9, and VEGF). An additional MSD panel with three markers (CSF, MMP-9, and VEGF) was also designed.

Total $\mathrm{NO}_{\mathrm{x}}$ levels, a crude measure of $\mathrm{NO}$ release, were assayed using slightly modified methods of Nitrate/Nitrite Fluorometric Assay kit methodology as described by manufacture (Cayman Chemical, Ann Arbor, Michigan) [54]. Serum samples were initially passed through a $30 \mathrm{kDa}$ molecular weight cut-off filter to remove hemoglobin. In addition to serum, tissue samples were also used in this assay. Tissues were reconstituted in cold PBS ( $\mathrm{pH}$ 7.4), homogenized, followed by centrifugation at $10,000 \mathrm{X}$ g for 20 minutes. Homogenate tissue samples were treated the same as serum samples and filtered through a $30 \mathrm{kDa}$ molecular weight cut-off filter to remove large tissue pieces. Ten $\mu \mathrm{l}$ of the filtered samples were then used in the assay per the manufacture's protocol.

\section{Vascular function}

Vascular function was measured in second order mesenteric arteries $(\sim 60 \mu \mathrm{m}$ in diameter). To measure contractile and dilatory responses, the complete mesenteric was extracted and 2-mm long segments were cut and mounted on a 4-channel wire myograph (multi-Myograph; 610 M, Danish Myo Technology, Aarhus N, Denmark). Each segment was placed in an individual organ chambers baths filled with physiological salt solution buffer (PSS: $\mathrm{NaCl}, 119 ; \mathrm{KCl}, 4.7 ; \mathrm{NaHCO}_{3}, 25 ; \mathrm{MgSO}_{4} \cdot 7 \mathrm{H}_{2} 0,1.17$; $\mathrm{KH}_{2} \mathrm{PO}_{4}, 1.18 ; \mathrm{CaCl}_{2} \cdot 2 \mathrm{H}_{2} 0$, 2.5; glucose, 5.5; EDTA, 0.027 $\mathrm{mM}$, maintained at $37^{\circ} \mathrm{C}, \mathrm{pH} 7.4$ and aerated with a gas mixture of $95 \% \mathrm{O}_{2}-5 \% \mathrm{CO}_{2} \mathrm{pH}, 7.4$; as described by [45]). The chambers were kept at $37^{\circ} \mathrm{C}$ and continuously aerated with $5 \%$ carbon dioxide balanced in $95 \%$ oxygen. Mounted vessels were allowed to equilibrate for at least 1 hour to a resting distaining pressure equivalent to $120 \mathrm{mmHg}$ before being subjected to graded doses of agonists. After vessels equilibrated in physiological buffer solution (PBS), vessel 
Table 2 Number of animals per exposure group, duration, and biological assessments

\begin{tabular}{|c|c|c|c|c|c|}
\hline Exposure time & $\mathbf{N}$ & PM sample & $\begin{array}{l}\text { PM nominal } \\
\text { concentration }\end{array}$ & $\begin{array}{l}\text { Collected tissues/ } \\
\text { biological fluids }\end{array}$ & Biological assessment \\
\hline $1 x$ & \multirow[t]{6}{*}{6} & $J C$ & \multirow[t]{8}{*}{$0.5 \mu \mathrm{g}$} & \multirow[t]{8}{*}{ BALF } & \multirow{8}{*}{$\begin{array}{l}\text { BALF evaluation of cell differentials, } \\
\text { counts, and protein concentration }\end{array}$} \\
\hline $1 x$ & & $\mathrm{ZH}$ & & & \\
\hline $1 x$ & & $\mathrm{ZH}+\mathrm{NiSO}^{4}$ & & & \\
\hline $1 x$ & & $\mathrm{ZH}+\mathrm{CuSO}^{4}$ & & & \\
\hline $1 x$ & & $\mathrm{ZH}+\mathrm{AsO}_{3}$ & & & \\
\hline $1 x$ & & $\mathrm{ZH}+\mathrm{SeCl}_{4}$ & & & \\
\hline $1 x$ & \multirow[t]{2}{*}{4} & $\mathrm{NiSO}_{4}+\mathrm{H}_{2} \mathrm{O}$ & & & \\
\hline $1 x$ & & $\mathrm{NiSO}_{4}+$ Carbon & & & \\
\hline $1 x$ & 8 & $J C$ & $0.25 \mu \mathrm{g}$ & BALF, Blood & \multirow{9}{*}{$\begin{array}{l}\text { BALF evaluation of cell differentials, counts, } \\
\text { and protein, various inflammation and } \\
\text { vascular dysfunction, vessel function }\end{array}$} \\
\hline 3 wks & 14 & & & BALF, Blood, Mesenteric Artery & \\
\hline \multicolumn{5}{|l|}{$2 x / w k$} & \\
\hline $1 x$ & 8 & $\mathrm{ZH}$ & & BALF, Blood & \\
\hline $3 w k s$ & 8 & & & BALF, Blood, Mesenteric Artery & \\
\hline \multicolumn{5}{|l|}{$2 x / w k$} & \\
\hline $1 x$ & 8 & $\mathrm{ZH}+\mathrm{NiSO}^{4}$ & & BALF, Blood & \\
\hline 3 wks & 16 & & & BALF, Blood, Mesenteric Artery & \\
\hline $2 x / w k$ & & & & & \\
\hline
\end{tabular}

$\mathrm{H}_{2} \mathrm{O}$ controls were matched to each exposure group.

viability was assessed using a standard challenge of $\mathrm{KCl}$ incubation [55] and as such each experiment was initiated by pre-contracting the vessels with $60 \mathrm{mM}$ of nonspecific depolarizing agent $\mathrm{K}^{+}$-PSS (in $\mathrm{mM}: \mathrm{NaCl}, 74.7 ; \mathrm{KCl}, 60$; $\mathrm{NaHCO}_{3}, 14.9 ; \quad \mathrm{MgSO}_{4} \cdot 7 \mathrm{H}_{2} 0,1.17 ; \mathrm{KH}_{2} \mathrm{PO}_{4}, 1.18$; $\mathrm{CaCl}_{2}$, 1.6; glucose, 5.5; $\mathrm{CaNa}_{2}, 0.026$; EDTA, 0.027; $37^{\circ} \mathrm{C}, \mathrm{pH} 7.4$ ), followed by contracting the vessels with $120 \mathrm{mM} \mathrm{K}{ }^{+}$-PSS (in $\mathrm{mM}: \mathrm{NaCl}, 14.7 ; \mathrm{KCl}, 120$; $\mathrm{NaHCO}_{3}, 14.9 ; \quad \mathrm{MgSO}_{4} \bullet 7 \mathrm{H}_{2} 0,1.17 ; \mathrm{KH}_{2} \mathrm{PO}_{4}, 1.18$; $\mathrm{CaCl}_{2}$, 1.6; glucose, 5.5; $\mathrm{CaNa}_{2}, 0.026$; EDTA, 0.027; $37^{\circ} \mathrm{C}, \mathrm{pH} 7.4$ ) to stimulate calcium channel function, hence contractile function $[16,45,51,55]$. Shortly after, the vessels were washed and allowed to equilibrate to their resting state before beginning procedures for graded dose responses.

\section{Grades dose response}

Phenylephrine (PE) was added in graded doses (1 nM to $3 \mu \mathrm{M}$ ) to evaluate vascular function (42; Sigma-Aldrich, St. Louis, MO). PE responses were expressed as a percentage of the peak response to $120 \mathrm{mM} \mathrm{KCI}$ of potassium chloride $(\mathrm{KCl})$. Vessels were then washed and once equilibrated, vasorelaxation was tested by pre-contracting the segments with $1 \mu \mathrm{M} \mathrm{PE}$ and subsequently relaxing them with increasing concentrations ( $1 \mathrm{nM}$ to $3 \mu \mathrm{M})$ of either acetylcholine $(\mathrm{ACh})$ or sodium nitroprusside (SNP; SigmaAldrich, St. Louis, MO) per previous methodology [16,45]. Results yielded from the ACh and SNP stimuli were expressed as a percentage of pre-contraction by $\mathrm{PE}$
$(1 \mu \mathrm{M})$. The half-maximal (either for dilation or contraction), dose for each vessel, as well as the maximum contraction and relaxation values were used to compare treatment groups as described in Quan et al. [45].

\section{Inhibitors and antioxidants for vascular function study}

Vessels were incubated with various inhibitors for $30 \mathrm{mi}$ nutes prior to conducting $\mathrm{PE}$, ACh or SNP response curves. NO synthase inhibitor, NW-nitro-L-arginine methyl ester (L-NAME $100 \mu \mathrm{M}$; Sigma Aldrich), NADPH oxidase was inhibited by a non-specific inhibitor (Apocynin $100 \mu \mathrm{M})$ and a specific and novel inhibitor, 3-Benzyl-7-(2benzoxazolyl)thio-1,2,3-triazolo(4,5-d)pyrimidine (VAS2870 $10 \mu \mathrm{M}$; both from Sigma Aldrich St. Louis, MO). 1H[2,12,55] Oxadiazolo[4,3-a]quinoxalin-1-one (ODQ $10 \mu \mathrm{M}$; Sigma Aldrich St. Louis, MO), a guanylyl cyclase inhibitor, was also incubated with some vessels for 30 minutes prior to usage of PE, ACh or SNP. To protect against the potential deleterious effects of ROS, separate vessels, ex vivo, were incubated for 30 minutes with an antioxidant, Nacetyl cysteine (NAC $20 \mathrm{mM}$; Sigma Aldrich, St. Louis, $\mathrm{MO})$, and the above myograph procedure was conducted as described above.

\section{Quantitative RT-PCR}

After isolation of the mesenteric arteries used for the vascular response study, the remainder of the mesenteric organ was stored in RNAlater ${ }^{\circledR}$ Solution (Ambion, Austin, $\mathrm{TX}, \mathrm{USA})$ at $-20^{\circ} \mathrm{C}$ until further processing. Total RNA 
was then extracted from individual isolated arteries using RNeasy Micro Elute kit (Qiagen, Valencia, CA, USA) and treated for genomic DNA contamination (4 arteries/ mouse $=1$ sample; $n=6 / g r p)$. The quality and concentration was determined using a Nanodrop 1000 spectrometer (Thermo Fisher Scientific, Wilmington, DE, USA). RNA was then transcribed into cDNA by using High Capacity cDNA Reverse Transcription Kits (Applied Biosystems, Foster City, CA, USA). The relative mRNA levels were quantified using an Applied Biosystems 7900 Real-Time PCR Instrument (Applied Biosystems, Foster City, CA) with TaqMan Gene Expression Assay primer/ probe sets following the provided manufacturer's protocol. Since all genes of interest were linear, the relative mRNA expression levels were calculated using the $\Delta \Delta \mathrm{Ct}$ method and normalized to the housekeeping gene, $\beta$-actin.

\section{Statistics}

All statistical analyses were performed using GraphPad Prism software (V4.0, GraphPad Software Inc, San Diego, CA). An unpaired Student's $t$-test was used to compare the means of two groups of one independent variable/factor. One-way analysis of variance (ANOVA) was utilized for comparison of more than two groups of one factor (e.g. exposure treatment). A two-way ANOVA test was performed if the means of more than two groups of at least two factors (e.g. exposure treatment and exposure duration) were evaluated. Following ANOVA analyses, if the null hypothesis was rejected, then one of the following post-hoc analyses were utilized: the Newman-Keuls test for all pairwise comparisons or the Dunnett's test for comparison of group means against the control mean.

Maximal contraction or relaxation data from vascular response was fit to a sigmoidal dose-response curves using nonlinear regression analysis and expressed as mean \pm standard error (SE) unless otherwise noted. Statistical significance of treatment related vascular responses in comparison to control groups were determined by one-way ANOVA followed by Dunnett's post hoc test analysis and $\mathrm{P}<0.05$ was considered significant.

\footnotetext{
Abbreviations

As: Arsenic; CSF: Colony stimulating factor; Cu: Copper; CVD: Cardiovascular disorder; eNOS: Endothelial nitric oxide synthesis; ICAM-1: Inter-cellular adhesion molecule-1; IL-6: Interleukin-6; IL-10: Interleukin-10; IL-13: Interleukin-13; JC: Jinchang; MCP-1: Monocyte chemotactic protein-1; MMP-9: Metalloproteinase 9; NADPH: Nicotinamide Adenine Dinucleotide Phosphate; Ni: Nickel; $\mathrm{NiSO}_{4}$ : Nickel Sulfate; ROS: Reactive oxygen species; PM: Particulate matter; $\mathrm{PM}_{2.5}$ : Particulate matter less than $2.5 \mu \mathrm{m}$ in size; Se: Selenium; TNF-a: tumor necrosis factor-alpha; VCAM-1: Vascular cell adhesion molecule-1; VEGF: Vascular endothelial growth factor; ZH: Zhangye; iNOS: inducible endothelial nitric oxide synthesis.
}

\section{Competing interests}

The authors declare that they have no competing interests.

\section{Authors' contributions}

AKC conceived, designed, coordinated, and performed all experiments, as well as the statistical analysis, and drafted the manuscript. JN collaborated from China and collected all the PM samples. MZ assisted in particle analysis. ENL assisted in study design, and manuscript editing. AG performed all Mesoscale analysis. QQ collaborated with China collaborators on larger study development, particle collection and analysis. LCC aided in study conception, design and assisted in manuscript preparation. All authors read and approved the final manuscript.

\section{Acknowledgements}

Authors would like to acknowledge Drs. Morton Lippmann, Qinghua Sun, Matthew Campen, and Terry Gordon for their critical reviews of this manuscript.

\section{Funding sources}

This study was supported by R01ES015495 (Chen, LC), NIH Fellowship: F31 ES018236 (Cuevas, AK), Center Grant ES00260 (Chen, LC; NYU), and CIHR-DRA (Liberda, EN).

\section{Author details}

'Department of Environmental Medicine, New York University School of Medicine, 57 Old Forge Road, Tuxedo 10987, NY, USA. 'Lanzhou University School of Public Health, Lanzhou, China. ${ }^{3}$ Human Studies Division, NHEERL, USEPA, Research Triangle Park, Chapel Hill, NC, USA.

Received: 30 July 2014 Accepted: 23 December 2014

Published online: 04 June 2015

\section{References}

1. World Health Organization. Global Health Risks: mortality and burden of disease attributable to selected major risks. 2009

2. Andersen ZJ, Raaschou-Nielsen O, Ketzel M, Jensen SS, Hvidberg M, Loft S, et al. Diabetes incidence and long-term exposure to air pollution: a cohort study. Diabetes Care. 2012;35:92-8.

3. Sun Q, Yue P, Ying Z, Cardounel AJ, Brook RD, Devlin R, et al. Air pollution exposure potentiates hypertension through reactive oxygen speciesmediated activation of Rho/ROCK. Arterioscler Thromb Vasc Biol. 2008;28(10):1760-6.

4. Tong H, Cheng WY, Samet JM, Gilmour MI, Devlin RB. Differential cardiopulmonary effects of size-fractionated ambient particulate matter in mice. Cardiovasc Toxicol. 2010;10(4):259-67.

5. Mills NL, Donaldson K, Hadoke PW, Boon NA, MacNee W, Cassee FR, et al. Adverse cardiovascular effects of air pollution. Nat Clin Pract Cardiovasc Med. 2009;6(1):36-44.

6. Pope III CA, Burnett RT, Krewski D, Jerrett M, Shi Y, Calle EE, et al. Cardiovascular mortality and exposure to airborne fine particulate matter and cigarette smoke: shape of the exposure-response relationship. Circulation. 2009:120(11):941-8.

7. Ghio A, Devlin R. Inflammatory lung injury after bronchial instillation of air pollution particles. Am J Respir Crit Care Med. 2001;164(4):704-8.

8. Ghio A, Hall A, Bassett M, Cascio W, Devlin R. Exposure to concentrated ambient air particles alters hematologic indices in humans. Inhal Toxicol. 2003;15(14):1465-78.

9. Graff D, Cascio W, Rappold A, Zhou H, Huang Y, Devlin R. Exposure to concentrated coarse air pollution particles causes mild cardiopulmonary effects in healthy young adults. Environ Health Perspect. 2009;117(7):1089-94.

10. Sangani RG, Soukup JM, Ghio AJ. Metals in air pollution particles decrease whole-blood coagulation time. Inhal Toxicol. 2010;22(8):621-6.

11. Chu A. Tissue factor, blood coagulation, and beyond: an overview. Int J Inflamm. 2011;2011:1-30. Online.

12. Campen MJ, Nolan JP, Schladweiler MC, Kodavanti UP, Evansky PA, Costa DL, et al. Cardiovascular and thermoregulatory effects of inhaled PM-associated transition metals: a potential interaction between nickel and vanadium sulfate. Toxicol Sci. 2001;64(2):243-52.

13. Graff D, Cascio W, Brackhan J, Devlin R. Metal particulate matter components affect gene expression and beat frequency of neonatal rat ventricular myocytes. Environ Health Perspect. 2004;112(7):792-8.

14. Kwon S, Weiden MD, Echevarria GC, Comfort AL, Naveed B, Prezant DJ, et al Early Elevation of Serum MMP-3 and MMP-12 Predicts Protection from World Trade Center-Lung Injury in New York City Firefighters: A Nested Case-control Study. PLoS One. 2013;8(10):1-8. 
15. Lippmann M, Ito K, Hwang J, Maciejczyk P, Chen L. Cardiovascular effects of nickel in ambient air. Environ Health Perspect. 2006;114(11):1662.

16. Cuevas AK, Liberda EN, Gillespie PA, Allina J, Chen LC. 2010, Inhaled nickel nanoparticles alter vascular reactivity in C57BL/6 mice. Inhal Toxicol. 2010;22 Suppl 2:100-6

17. Kang G, Gillespie P, Gunnison A, Moreira A, Tchou Wong K, Chen L. Long-term inhalation exposure to nickel nanoparticles exacerbated atherosclerosis in a susceptible mouse model. Environ Health Perspect. 2011;119(2):176-81.

18. Liberda E, Cuevas AK, Gillespie PA, Grunig G, Qu Q, Chen LC. Exposure to inhaled nickel nanoparticles causes a reduction in number and function of bone marrow endothelial progenitor cells. Inhal Toxicol. 2010;5:95-9.

19. Liberda EN, Cuevas AK, Qu Q, Chen LC. The acute exposure effects of inhaled nickel nanoparticles on murine endothelial progenitor cells. Inhal Toxicol. 2014;10:588-97.

20. Maciejczyk P, Chen LC. Effects of subchronic exposures to concentrated ambient particles (CAPs) in mice. VIII. Source-related daily variations in in vitro responses to CAPs. Inhal Toxicol. 2005;17(4-5):243-53.

21. Niu J, Liberda E, Qu S, Guo X, Li X, Luo B, et al. The role of metal components in the cardiovascular effects of PM 25. PLoS One. 2013;8(12):1-11.

22. Duvall RM, Norris GA, Dailey LA, Burke JM, McGee JK, Gilmour MI, et al. Source apportionment of particulate matter in the U.S. and associations with lung inflammatory markers. Inhal Toxicol. 2008;20(7):671-83.

23. Forti $E$, Salovaara $S$, Cetin $Y$, Bulgheroni $A$, Tessadri $R$, Jennings $P$, et al. In vitro evaluation of the toxicity induced by nickel soluble and particulate forms in human airway epithelial cells. Toxicol In Vitro. 2011;25(2):454-61.

24. Harrison DG. Cellular and molecular mechanisms of endothelial cell dysfunction. J Clin Invest. 1997;100(9):2153-7.

25. Chen LC, Hwang JS, Lall R, Thurston G, Lippmann M. Alteration of cardiac function in ApoE-/- mice by subchronic urban and regional inhalation exposure to concentrated ambient PM 2.5. Inhal Toxicol. 2010;22(7):580-92

26. Rao GV, Tinkle S, Weissman DN, Antonini JM, Kashon ML, Salmen R, et al. Efficacy of a technique for exposing the mouse lung to particles aspirated from the pharynx. J Toxicol Environ Health. 2003;66:1441-52.

27. Robbie L, Libby P. Inflammation and atherothrombosis. Ann N Y Acad Sci. 2001;947:167-79.

28. Gillespie PA, Kang GS, Elder A, Gelein R, Chen L, Moreira AL, et al. Pulmonary response after exposure to inhaled nickel hydroxide nanoparticles: short and long-term studies in mice. Nanotoxicology. 2010;4(1):106-19.

29. Donaldson K, Stone V, Seaton A, MacNee W. Ambient particle inhalation and the cardiovascular system: potential mechanisms. Environ Health Perspect. 2001;109 Suppl 4:523-7.

30. Saldiva PHN, Clarke RW, Coull BA, Stearns RC, Lawrence J, Murthy GGK, et al. Lung inflammation induced by concentrated ambient Air particles is related to particle composition. Am J Respir Crit Care Med. 2002;165(12):1610-7.

31. Moller P, Mikkelsen L, Vesterdal LK, Folkmann JK, Forchhammer L, Roursgaard M, et al. Hazard identification of particulate matter on vasomotor dysfunction and progression of atherosclerosis. Crit Rev Toxicol. 2011;41(4):339-68

32. Nurkiewicz TR, Porter DW, Hubbs AF, Cumpston JL, Chen BT, Frazer DG, et al. Nanoparticle inhalation augments particle-dependent systemic microvascular dysfunction. Part Fibre Toxicol. 2008:5:1-12.

33. Stark M, Zubareb J, Jacovovitz R, Schwartz Y, Lerman Y, Grinberg N, et al. HO-1 and VEGF gene expressions are time dependant during exposure to welding fumes. Cytokine. 2009;46(2):290-5.

34. Papaioannou A, Kostikas K, Kollia P, Gourgoulianis K. Clinical implications for vascular endothelial growth factor in the lung: friend or foe? Respir Res. 2006;7:128-40.

35. Haberzettl P, Lee J, Duggineni D, McCracken J, Bolanowski DD, OToole T, et al. Exposure to ambient Air fine particulate matter prevents VEGF-induced mobilization of endothelial progenitor cells from the bone marrow. Environ Health Perspect. 2012;120(6):848.

36. Salnikow K, Donald S, Bruick R, Zhitkovich A, Phang J, Kasprzak K. Depletion of intracellular ascorbate by the carcinogenic metals nickel and cobalt results in the induction of hypoxic stress. J Biol Chem. 2004;279(39):40337-44.

37. Hoeben A, Landuyt B, Highley MS, Wildiers H, Van Oosterom AT, De Bruijn EA. Vascular endothelial growth factor and angiogenesis. Pharmacol Rev. 2004;56(4):549-80.

38. Munjal C, Givvimani S, Qipshidze N, Tyagi N, Falcone JC, Tyagi SC. Mesenteric vascular remodeling in hyperhomocysteinemia. Mol Cell Biochem. 2011;348(1-2):99-108.
39. Lund AK, Knuckles TL, Obot Akata C, Shohet R, McDonald JD, Gigliotti A, et al. Gasoline exhaust emissions induce vascular remodeling pathways involved in atherosclerosis. Toxicol Sci. 2007;95(2):485-94.

40. Lund A, Lucero J, Lucas S, Madden M, McDonald J, Seagrave J, et al. Vehicular emissions induce vascular MMP-9 expression and activity associated with endothelin-1-mediated pathways. Arterioscler Thromb Vasc Biol. 2009;29(4):511-7.

41. Bouloumie A, Bauersachs J, Linz W, Scholkens BA, Wiemer G, Fleming I, et al Endothelial dysfunction coincides with an enhanced nitric oxide synthase expression and superoxide anion production. Hypertension. 1997;30(4):934-41.

42. Cosentino F, Hishikawa K, Katusic ZS, LÃafscher TF. High glucose increases nitric oxide synthase expression and superoxide anion generation in human aortic endothelial cells. Circulation. 1997;96(1):25-8.

43. Hickey AJ, Martonen TB, Yang Y. Theoretical relationship of lung deposition to the fine particle fraction of inhalation aerosols. Pharm Acta Helv. 1996;71(3):185-90.

44. Jacobson (Cuevas) A, Yan C, Gao Q, Rincon-Skinner T, Rivera A, Edwards J, et al. Aging enhances pressure-induced arterial superoxide formation. Am J Physiol Heart Circ Physiol. 2007;293(3):H1344-50.

45. Quan C, Sun Q, Lippmann M, Chen LC. Comparative effects of inhaled diesel exhaust and ambient fine particles on inflammation, atherosclerosis, and vascular dysfunction. Inhal Toxicol. 2010;22(9):738-53.

46. Nurkiewicz TR, Porter DW, Barger M, Millecchia L, Rao KM, Marvar PJ, et al. Systemic microvascular dysfunction and inflammation after pulmonary particulate matter exposure. Environ Health Perspect. 2006;114(3):412-9.

47. Upadhyay S, Stoeger T, Harder V, Thomas RF, Schladweiler MC, SemmlerBehnke $\mathrm{M}$, et al. Exposure to ultrafine carbon particles at levels below detectable pulmonary inflammation affects cardiovascular performance in spontaneously hypertensive rats. Part Fibre Toxicol. 2008;5:1-18.

48. LeBlanc AJ, Cumpston JL, Chen BT, Frazer D, Castranova V, Nurkiewicz TR. Nanoparticle inhalation impairs endothelium-dependent vasodilation in subepicardial arterioles. J Toxicol Environ Health. 2009;72(24):1576.

49. LeBlanc AJ, Moseley AM, Chen BT, Frazer D, Castranova V, Nurkiewicz TR. Nanoparticle inhalation impairs coronary microvascular reactivity via a local reactive oxygen species-dependent mechanism. Cardiovasc Toxicol. 2010;10(1):27.

50. Sun Q, Wang A, Jin X, Natanzon A, Duquaine D, Brook RD, et al. Long-term Air pollution exposure and acceleration of atherosclerosis and vascular inflammation in an animal model. JAMA. 2005;294(23):3003-10.

51. Ying Z, Kampfrath $T$, Thurston G, Farrar B, Lippmann M, Wang A, et al. Ambient particulates alter vascular function through induction of reactive oxygen and nitrogen species. Toxicol Sci. 2009;111(1):80-8.

52. Kampfrath T, Maiseyeu A, Ying Z, Shah Z, Deiuliis JA, Xu X, et al. Chronic fine particulate matter exposure induces systemic vascular dysfunction via NADPH oxidase and TLR4 pathways. Circ Res. 2011;108(6):716-26.

53. Zhang YS, Ma GX, Yu F, Cao D. Health damage assessment due to PM2.5 exposure during haze pollution events in Beijing-Tianjin-Hebei region in January 2013. Zhonghua Yi Xue Za Zhi. 2013;93(34):2707-10.

54. Misko TP, Schilling RJ, Salvemini D, Moore WM, Currie MG. A fluorometric assay for the measurement of nitrite in biological samples. Anal Biochem. 1993;214(1):11-6.

55. Aalkjaer C, Heagerty AM, Petersen KK, Swales JD, Mulvany MJ. Evidence for increased media thickness, increased neuronal amine uptake, and depressed excitation-contraction coupling in isolated resistance vessels from essential Hypertensives. Circ Res. 1987;61(2):181-6.

\section{Submit your next manuscript to BioMed Central and take full advantage of:}

- Convenient online submission

- Thorough peer review

- No space constraints or color figure charges

- Immediate publication on acceptance

- Inclusion in PubMed, CAS, Scopus and Google Scholar

- Research which is freely available for redistribution 